\title{
ERRATUM: Online information on chia seeds - A systematic content analysis
}

\section{T. BICZOK ${ }^{1 *}$, SZ. KASSAI ${ }^{2}$ and V.A. GYARMATHY ${ }^{3}$}

\section{Developments in Health Sciences}

$3(2020) 3,77$

DOl:

$10.1556 / 2066.2019 .100$

(c) 2020 The Author(s)

\section{ERRATUM}

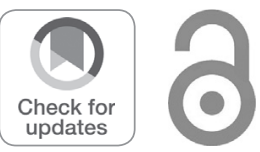

${ }^{1}$ Doctoral School of Pathological Sciences, Semmelweis University, Budapest, Hungary

${ }^{2}$ Institute of Psychology, Eötvös Lóránd University, Budapest, Hungary

${ }^{3}$ Johns Hopkins Bloomberg School of Public Health, Baltimore, MD, USA

ERRATUM: Developments in Health Sciences 2 (2019) 4, pp. 93-96

DOI: $10.1556 / 2066.2019 .00003$

The subtitle indicated incorrectly that the article was based on:

Oral presentation at the 13th Conference of the Hungarian Medical Association of America Hungary Chapter (HMAA-HC) at 30-31 August 2019, in Balatonfüred, Hungary.

This paper was not presented at HMAA-HC.

The authors apologize for this error.
* Corresponding author.
Open Access statement. This is an open-access article distributed under the terms of the Creative Commons AttributionNonCommercial 4.0 International License (https://creativecommons.org/licenses/by-nc/4.0/), which permits unrestricted use, distribution, and reproduction in any medium for non-commercial purposes, provided the original author and source are credited, a link to the CC License is provided, and changes - if any - are indicated. 